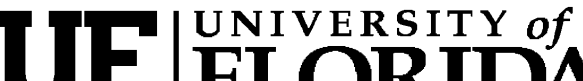 FLORIDA \\ IFAS Extension
}

\section{Texas Phoenix Palm Decline ${ }^{1}$}

Nigel A. Harrison and Monica L. Elliott ${ }^{2}$

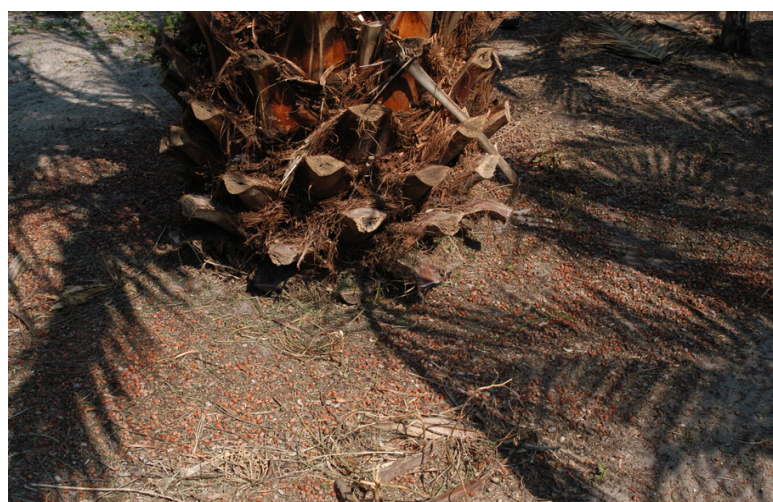

Figure 1. Premature fruit drop is an early symptom of TPPD. Virtually all the fruit drops at one time from the affected tree.

\section{Summary}

- Texas Phoenix palm decline (TPPD) is a new disease in Florida. This disease is caused by an unculturable bacterium that has no cell wall -- a phytoplasma.

- The TPPD phytoplasma is similar to, but genetically distinct from the phytoplasma that causes lethal yellowing (LY) disease of palms.
- Texas Phoenix palm decline is a fatal, systemic disease that kills palms quickly. The TPPD phytoplasma is spread naturally to palms by sap-feeding insects, such as planthoppers.

- Palms showing symptoms of more than 25 percent foliar discoloration or a dead spear leaf due to the disease should be removed immediately.

- Management of TPPD includes protection of susceptible palms in disease-active areas by

- trunk injection with oxytetracycline $\mathrm{HCl}$ (OTC) every four months and

- planting palm species that are not known to contract this disease.

- As of February 2009, palm species known to be most severely affected by TPPD were Phoenix canariensis (Canary Island date palm), Phoenix dactylifera (edible date palm), Phoenix sylvestris (wild date palm) and Sabal palmetto (cabbage palm).

1. This document is PP243, one of a series of the Plant Pathology Department, Florida Cooperative Extension Service, Institute of Food and Agricultural Sciences, University of Florida. Original publication date, November 2007. Revised February 2009. Visit the EDIS Web site at http://edis.ifas.ufl.edu. 2. Nigel A. Harrison, associate professor, and Monica L. Elliott, professor, Department of Plant Pathology, Fort Lauderdale Research and Education Center--Ft. Lauderdale, FL; Florida Cooperative Extension Service, Institute of Food and Agricultural Sciences, University of Florida.

The use of trade names in this publication is solely for the purpose of providing specific information. UF/IFAS does not guarantee or warranty the products named, and references to them in this publication does not signify our approval to the exclusion of other products of suitable composition. All chemicals should be used in accordance with directions on the manufacturer's label.

The Institute of Food and Agricultural Sciences (IFAS) is an Equal Opportunity Institution authorized to provide research, educational information and other services only to individuals and institutions that function with non-discrimination with respect to race, creed, color, religion, age, disability, sex, sexual orientation, marital status, national origin, political opinions or affiliations. U.S. Department of Agriculture, Cooperative Extension Service, University of Florida, IFAS, Florida A. \& M. University Cooperative Extension Program, and Boards of County Commissioners Cooperating. Interim Dean Millie Ferrer. 


\section{Introduction}

Until recently, lethal yellowing (LY) was the only palm disease in Florida caused by a phytoplasma. In late 2006, a second phytoplasma disease was identified in the coastal areas of Central Florida (from Sarasota to Tampa), affecting Phoenix (date) species. In early 2008, this second phytoplasma disease was confirmed as the cause of declining Sabal palmetto (cabbage palm) in Hillsborough and Manatee counties. The disease is known as Texas Phoenix palm decline because it was originally described in the southern coastal region of Texas on Phoenix canariensis (Canary Island date palm).

\section{Pathogen and Hosts}

Texas Phoenix palm decline is caused by a phytoplasma, an unculturable bacterium that has no cell wall. Among phytoplasmas, the TPPD agent has been classified as a member of $16 \mathrm{~S}$ rDNA RFLP group 16SrIV, subgroup D (16SrIV-D). The signature DNA sequence obtained from TPPD phytoplasma in Florida is a perfect match to the signature of the phytoplasma known to cause TPPD on P. canariensis (Canary Island date palm) in the Corpus Christi area of Texas. Analysis of DNA has determined the TPPD phytoplasma is related to, but genetically distinct from the phytoplasma that causes LY.

Phytoplasmas systemically colonize the phloem tissue (vascular tissue transporting photosynthates) of plants. Phytoplasmas are transmitted to plants by piercing-sucking insects that feed on phloem sap. The insects spread the phytoplasma from plant to plant as they visit different hosts during their feeding activities. Phytoplasmas are not known to survive outside their host, whether the host is plant or insect. Planthoppers, treehoppers or psyllids are the most-likely groups of insects to transmit phytoplasmas.

It is not known when the TPPD phytoplasma arrived in Florida, but considerable time would have been necessary for both the pathogen and the vector populations to establish and for TPPD disease incidence to increase to its present level in Florida.
The presence of TPPD phytoplasma has been confirmed in Florida in symptomatic $P$. canariensis (Canary Island date palm), $P$. dactylifera (edible date palm) or P. sylvestris (wild date palm) in landscape and field nursery sites in the following counties: Highlands, Lake, Sarasota, Manatee, Pinellas, and Hillsborough, as well as in western portions of Polk County. The TPPD phytoplasma has been most recently detected in Sabal palmetto (cabbage palm) in landscapes and natural areas in Hillsborough, Manatee, Sarastoa, Polk, DeSoto and Hardee counties. However, in 2008 the primary concentration of diseased cabbage palms in Florida was in southern Hillsborough County and in Manatee County.

A map illustrating sites in Florida where the disease has been confirmed can be found on the Florida Division of Plant Industry Web site, http://www.doacs.state.fl.us/pi/caps/TPPD_maps/ TPPD.pdf. This map will be periodically updated as new cases of the disease are verified.

How far and how quickly TPPD will spread to other Florida counties is unknown. However, since movement of palms occurs widely in Florida, it is likely people will unknowingly spread the disease by moving vector and infected hosts.

Currently, the known susceptible hosts for the TPPD phytoplasma are $P$. canariensis, P.dactylifera, $P$. sylvestris, $P$. reclinata, Sabal palmetto and Syagrus romanzoffiana (queen palm). Only a few queen palms in only three nursery sites -- one each in Hillsborough, Manatee and Pinellas counties -- have been confirmed with this disease, whereas the disease has been observed widely among Phoenix species in a five-county area (Sarasota, Manatee, Pinellas, Polk and Hillsborough counties).

\section{Symptoms}

The symptoms of this new disease appear to be exactly the same as those associated with LY of Phoenix species, with possibly one exception; root decay has been observed with TPPD.

The first obvious TPPD symptom on mature palms is premature drop of most or all fruits at one time (Figure 1). The fruit drop occurs within a few days. The fruit drop is not spread out over a prolonged 
period of time. Inflorescence (flower) necrosis (death) follows (Figure 2). However, these two symptoms will only be observed if the palm is mature enough to produce fruit, if it is the season for flowering and fruiting, and if the flowers or fruits have not been trimmed from the palm.

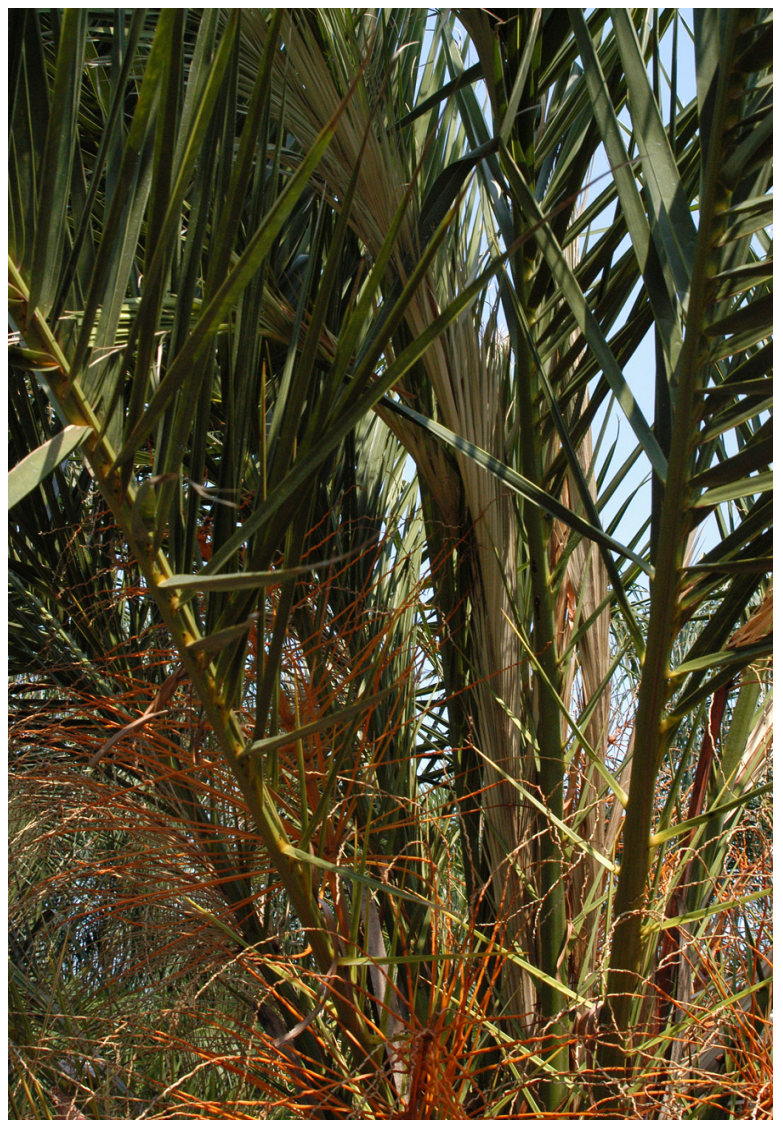

Figure 2. Death of the inflorescence (flowers) is an early symptom of TPPD. This photo also illustrates a dead spear leaf (youngest leaf that has not unfolded), which is tan and not green.

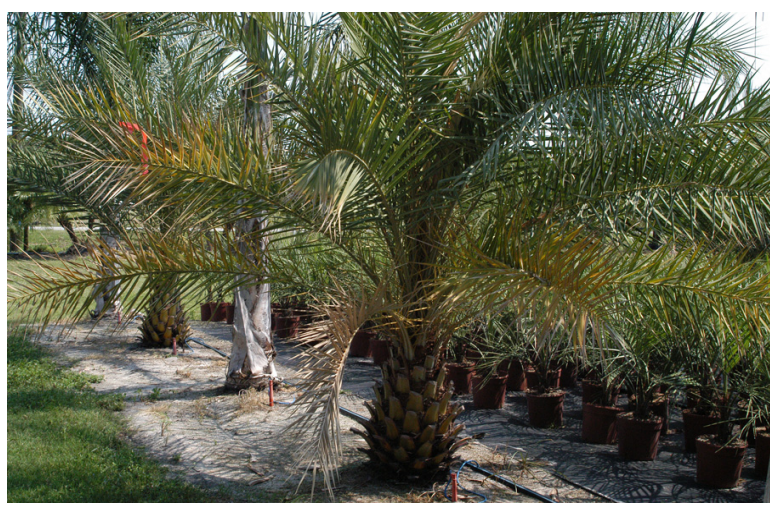

Figure 3. Discoloration of the lowest (oldest) leaves is an early symptom of TPPD.

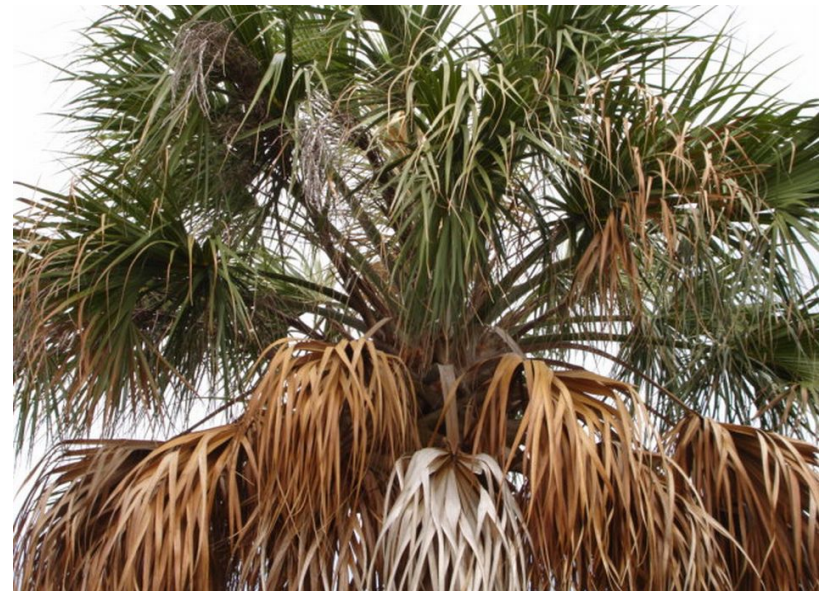

Figure 4. Discoloration of the lowest (older) leaves is an early symptom of TPPD in cabbage palm.

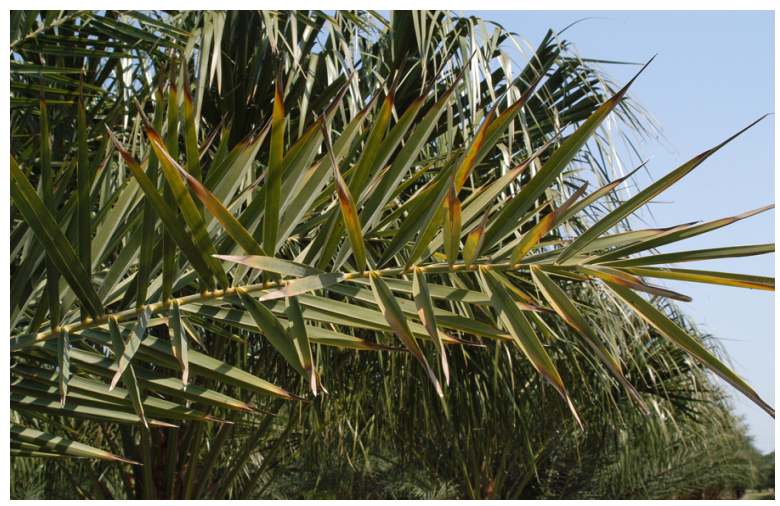

Figure 5. Discoloration of the leaves begins at the leaf tips.

The next symptom is discoloration of the foliage, beginning with the oldest leaves. The leaves do not turn yellow (or do so briefly), but quickly turn varying shades of reddish-brown to dark brown or gray (figures 3 and 4). The discoloration begins at leaf tips (Figure 5).

Unless the palm is being monitored closely, the onset of leaf discoloration is usually first recognized as a greater number of dead older leaves than is normal for natural senescence. This symptom might be confused with other problems, such as early senescence due to nutrient deficiency (e.g., potassium) or Ganoderma butt rot. However, if the dying or dead leaves are being regularly removed (nobody likes an untidy palm!), even this TPPD symptom of foliage discoloration and death may not be obvious. 


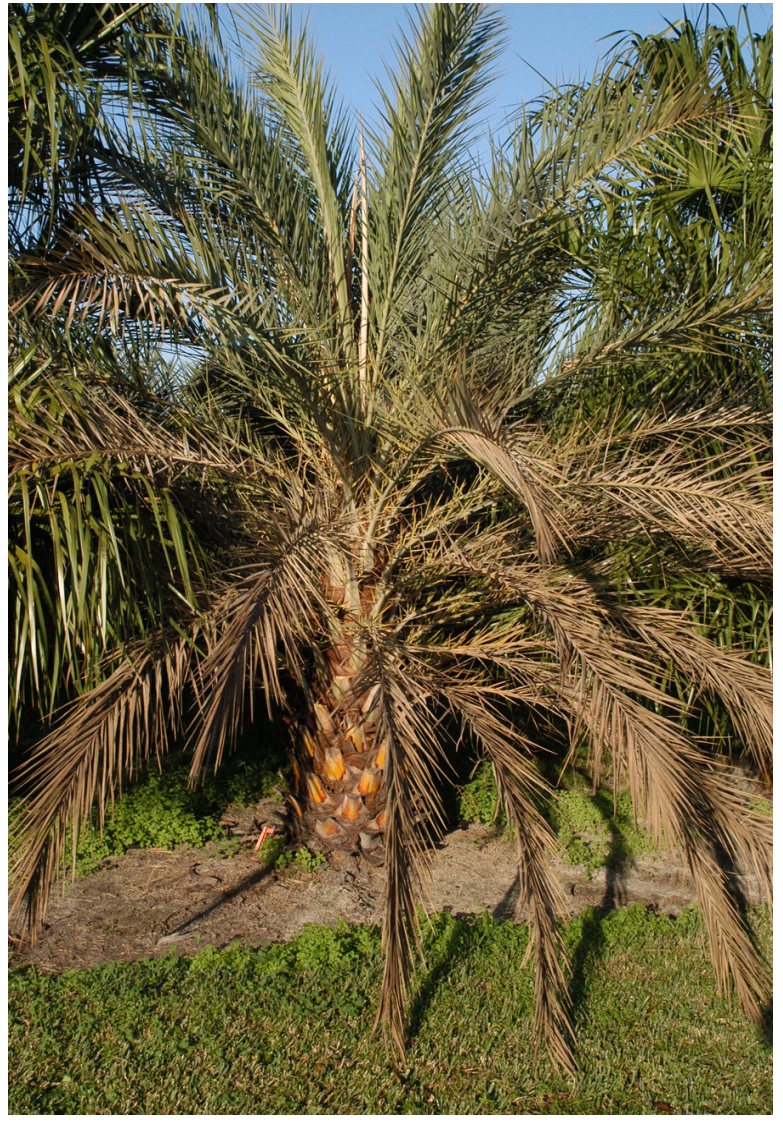

Figure 6. Phoenix sylvestris exhibiting symptoms of TPPD. Note more dead lower leaves than normal for a healthy palm. Also, the spear leaf (youngest leaf that has not unfolded) is tan and not green.

In Phoenix species, when less than one-third (and usually less than one-quarter) of the oldest leaves have discolored and become necrotic, the spear leaf dies (Figures 2, 6 and 7). Death of the spear leaf indicates the apical meristem (bud or heart) has died. Once the apical meristem has died, no new leaves will develop, and the remaining leaves will continue to discolor from the oldest to the youngest leaves. In cabbage palms, approximately two-thirds of the oldest leaves will have discolored before the spear leaf dies (Figure 8).

In some instances, by the time the spear leaf dies, mature roots of the palm at or near the soil surface are soft in texture and easily broken. The palm can be easily rocked back and forth in the ground because the root system is decaying. This symptom is not typical for palms affected by LY.

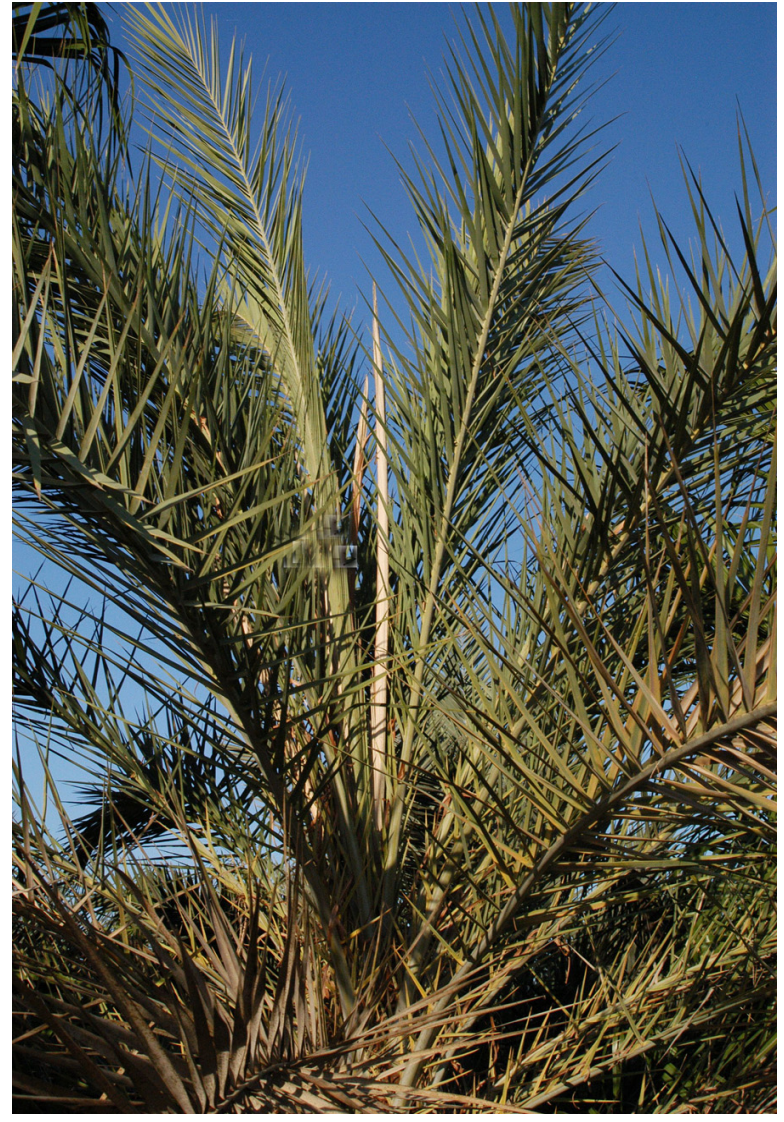

Figure 7. Close-up of dead spear leaf in Figure 6.

Death of the spear leaf may not always be obvious. Both Phoenix species and cabbage palms have numerous young leaves surrounding the spear leaf. Unless you see the spear leaf is dead (Figure 2 and 6) or find it hanging from the canopy (Figure 9) or on the ground, you will probably need to physically examine the canopy up close to determine whether a healthy spear leaf is present (Figure 10). Also, as the young spear leaf of Phoenix palms -- in normal, healthy conditions - is often enclosed in a thin, brown sheath (which tears like paper), be careful not to confuse the normally occurring brown sheath for a dead spear leaf.

Two juvenile queen palms have been diagnosed with the TPPD phytoplasma. Extensive root decay early in disease development was a common symptom to both palms. Leaf necrosis was exhibited on the lowest leaves first and continued upward through the canopy. It is not yet clear at what stage in the disease process the spear leaf dies, but initial observations indicate the spear leaf dies early in the 


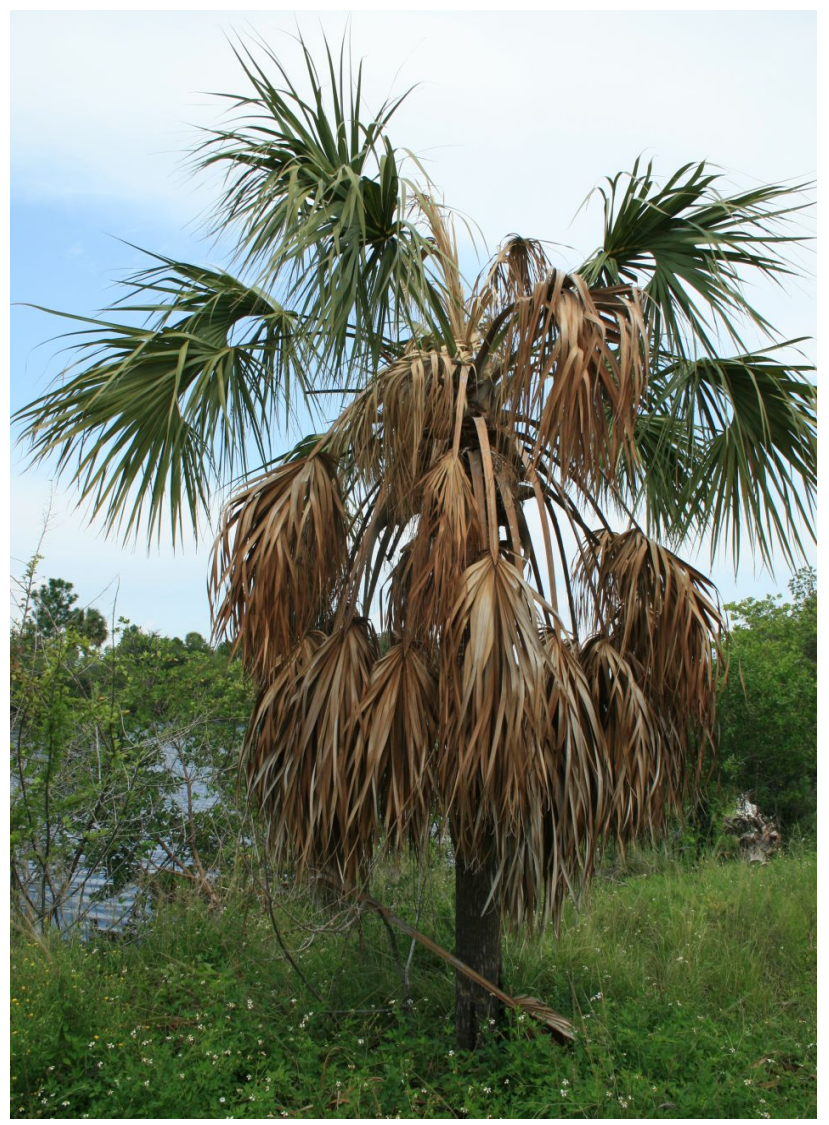

Figure 8. Sabal palmetto (cabbage palm), exhibiting symptoms of TPPD. Note more dead lower leaves than is normal for a healthy palm. Also, the spear leaf (youngest leaf) has died and is a tan color, rather than green.

disease process. The TPPD symptoms observed in these juvenile queen palms were distinctly different from Fusarium wilt, another new disease of queen palms. (For information on Fusarium wilt in queen palms, see the following:

http://flrec.ifas.ufl.edu/palm_prod/pdfs/New-DiseaseQueen-Palms-Mexican-Fan-Palms-July.pdf.)

\section{Diagnostics}

Initial diagnosis of TPPD is based on the palm symptoms described above. Since the phytoplasma is not culturable, a molecular diagnostic test is used to confirm the presence of the pathogen. If pathogen confirmation is necessary, contact your local county Extension office --

http://solutionsforyourlife.ufl.edu/map -- for information on sample submission and cost of

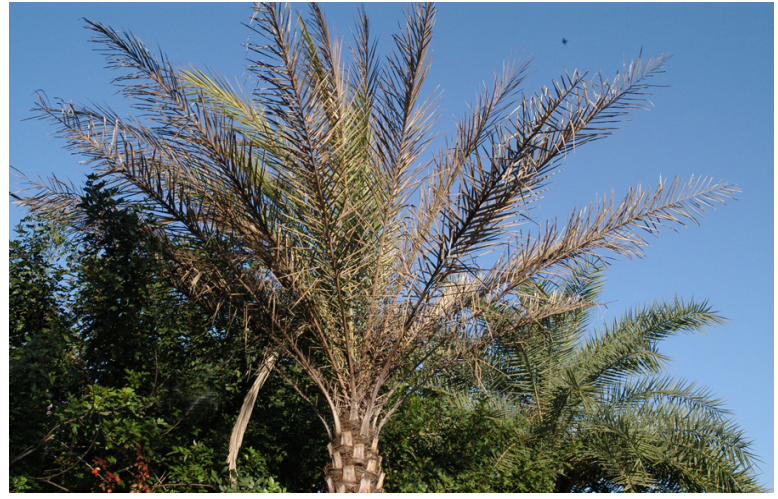

Figure 9. Note the spear leaf has died and is hanging down from the canopy of this Phoenix sylvestris affected by TPPD.

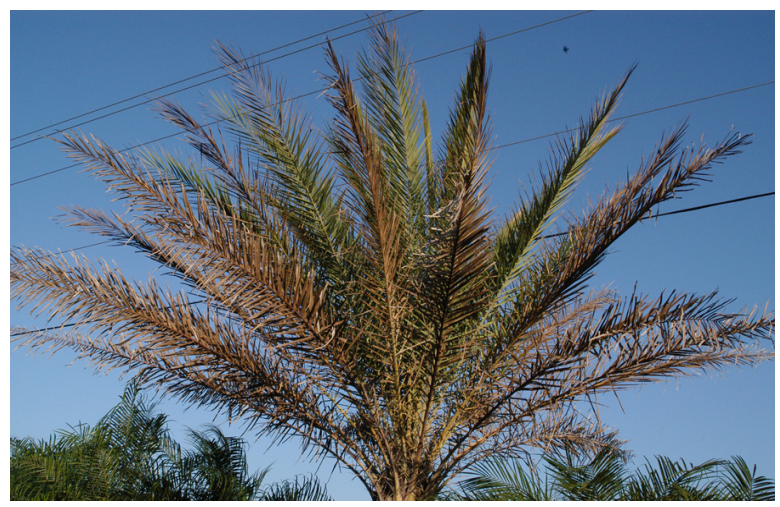

Figure 10. The spear leaf has already died in this Phoenix sylvestris, and the spear leaf has broken off from the canopy. Unlike the examples shown in figures 6, 7 and 9, without a close examination of the bud on this palm, it would not be apparent that the spear leaf had died.

laboratory diagnosis. This information is also available on the Web site for the UF/IFAS Fort Lauderdale Research and Education Center -http://flrec.ifas.ufl.edu/pdfs/LY-TPPD-TrunkSampling.pdf.

Sampling is accomplished by boring into the trunk. The sampling process requires a drill with a long, large-diameter drill bit. Do not obtain samples without first reviewing the complete set of instructions. The quality of the sample is critical for an accurate diagnosis.

It is currently not known how early in the disease cycle TPPD phytoplasma can be detected via trunk-tissue sampling. However, the TPPD phytoplasma is usually not detectable in palms that are not exhibiting symptoms. This phytoplasma may not be detectable until the spear leaf dies. 
Phytoplasma detection by means of testing a trunk tissue sample is like searching blindfolded for a red marble in a bowl that is mostly full of white marbles. If there is only one red marble (phytoplasma) in the bowl of white marbles (trunk tissue), the likelihood of selecting that red marble, if you were blind folded, would be slim. However, the likelihood of selecting a red marble increases as the number of red marbles increase.

The molecular test for the TPPD phytoplasma is best used to confirm the presence of the disease in symptomatic palms in a nursery or community in order to track the spread of the disease and to devise a management program for remaining, susceptible palms. The molecular test does not certify a palm is phytoplasma free.

Remember that palms die or appear to be dying for a number of reasons; Texas Phoenix palm decline is just one reason. Before submitting a sample, take the time to make the best possible field diagnosis.

\section{Disease Management}

If the spear leaf has died, the palm should be removed as soon as possible. Death of the spear leaf indicates the apical meristem (bud) has died, so no new growth will occur. Although lower leaves may remain green for a number of months after the spear leaf dies, it is in the best interest of the nursery grower or the community to remove the infectious palm as soon as possible. The diseased palm serves as a source of the phytoplasma that can be transmitted by an insect vector to still-healthy, TPPD-susceptible palms.

If TPPD symptoms are present, but the spear leaf has not died, therapeutic treatment of the disease may be achieved by application of the antibiotic oxytetracycline $\mathrm{HCl}$ (often referred to as OTC), administered to palms by liquid injection into the trunk. Treatments would continue for the life of the palm on a four-month treatment schedule.

The most effective use of the antibiotic is as a preventive treatment to protect susceptible palms when TPPD is known to occur in the area. Again, these preventative antibiotic treatments should be made every four months. However, only palms known to be susceptible should receive the treatments. To date, palms known to be most susceptible to TPPD are the following: Phoenix canariensis (Canary Island date palm), Phoenix dactylifera (edible date palm), Phoenix sylvestris (wild date palm) and Sabal palmetto (cabbage palm).

The only source for oxytetracycline $\mathrm{HCl}$-- a product registered by the U.S. Environmental Protection Agency (EPA) -- is TreeSaver ${ }^{\circledR}$ (http://www.palmtreesaver.com). This product is for distribution and use only in Florida. Please read and follow label directions. The Web site for the company provides helpful hints for successful use of this product.

As with LY, landscape disease management of TPPD via control of the vector population is not recommended, especially since the TPPD vector is unknown at this time. Use of host resistance represents the most practical long-term solution. However, the complete palm host range of this phytoplasma is probably not yet known.

\section{References}

Harrison, N. A., E. E. Helmick, M. L. Elliott. 2008. Lethal yellowing-type diseases of palms associated with phytoplasmas newly identified in Florida, USA. Annals of Applied Biology 153:85-94.

Harrison, N. A., M. Womack, M. L. Carpio. 2002. Detection and characterization of a lethal yellowing (16SrIV) group phytoplasma in Canary Island date palms affected by lethal decline in Texas. Plant Disease 86:676-681.

McCoy, R. E. 1975. Effect of oxytetracycline dose and stage of disease development on remission of lethal yellowing in coconut palm. Plant Disease 59:717-720.

McCoy, R. E. 1982. Use of tetracycline antibiotics to control yellows diseases. Plant Disease 66:539-542. 